Quim. Nova, Vol. 33, No. 1, 104-108, 2010

\title{
CHEMICAL COMPOSITION AND ANTIBACTERIAL ACTIVITIES FROM THE ESSENTIAL OILS OF MYRTACEAE SPECIES PLANTED IN BRAZIL
}

\author{
Cleber J. Silva \\ Departamento de Biologia Vegetal, Universidade Federal de Viçosa, Av. PH Rolfs, s/n, 36570-000 Viçosa - MG, Brasil \\ Luiz C. A. Barbosa*, Antonio J. Demuner e Ricardo M. Montanari \\ Departamento de Química, Universidade Federal de Viçosa, Av. PH Rolfs, s/n, 36570-000 Viçosa - MG, Brasil \\ Antônio L. Pinheiro \\ Departamento de Engenharia Florestal, Universidade Federal de Viçosa, Av. PH Rolfs, s/n, 36570-000 Viçosa - MG, Brasil \\ Iara Dias e Nélio J. Andrade \\ Departamento de Tecnologia de Alimentos, Universidade Federal de Viçosa, Av. PH Rolfs, s/n, 36570-000 Viçosa - MG, Brasil
}

Recebido em 10/2/09; aceito em 24/6/09; publicado na web em 13/11/09

\begin{abstract}
The essential oils of seven Myrtaceae species were investigated for its chemical composition and antibacterial activity. The volatile oils were characterized by a high content of monoterpenoids of which 1,8-cineole (88.0,65.0 and 77.0\% for Melaleuca hypericifolia, Callistemon viminalis and Callistemon citrinus respectively), terpinen-4-ol (47.0 and 49.8\% for Melaleuca thymifolia and Callistemon polandii respectively) and $\alpha$-pinene (54.5\% for Kunzea ericoides) were the major components. The oil from M. linariifolia was characterized by a high concentration of methyleugenol (87.2\%). The oil from Melaleuca thymifolia was the most active, exhibiting high antimicrobial activity against all tested bacteria.
\end{abstract}

Keywords: Myrtaceae; antibacterial activity; Melaleuca.

\section{INTRODUCTION}

The development of microbial resistance to antibiotics is a global concern. In the recent decades, antimicrobial of plant origin have gained special attention because of the resistance to antibiotics that some microorganisms have acquired. ${ }^{1}$ Indeed, the committee on Food Safety (FAO/WHO) concluded that foodborne illness due to contaminated food was perhaps the most widespread health problem in the world. ${ }^{2}$ In this context the identification and evaluation of natural products for the control of foodborne pathogens, to assure consumers a safe, wholesome food supply, can be an important international issue. Many spices and herbs may serve as potential alternatives since their essential oils possess antimicrobial activity. ${ }^{3}$ There is considerable interest in the possible use of these oils as food additives, to delay the onset of food spoilage or to prevent the growth of foodborne pathogens and microorganisms resistant to antibiotics. Among these pathogens Bacilus cereus, Escherichia coli and Staphylococcus aureus are of great importance.

The genus Melaleuca L. (Myrtaceae) occurs predominantly in Australia and comprises approximately 250 described species. ${ }^{4}$ Volatile compounds of great economic importance can be found in the species of the Melaleuca genus. Moreover, leaves and stem of several Melaleuca species are source of essential oils used for medicinal purposes. Many of such oils present anti-inflammatory, ${ }^{5}$ fungicide, ${ }^{6}$ acaricide, ${ }^{7}$ antiviral ${ }^{8}$ properties and are also active against Gram-positive and Gram-negative bacteria. ${ }^{9}$ Besides, the essential oils of $M$. alternifolia and related species exhibit activity against herpes simplex virus (HSV), causal agent of labial herpes. ${ }^{10}$ The oil is also used for treatment of human melanoma, ${ }^{11}$ insect bites, skin infections, ${ }^{12}$ subcutaneous infections caused by fungi, ${ }^{13}$ oral and genital candidiasis, ${ }^{14}$ treatment of methicillin-resistant Staphylococcus aureus ${ }^{15}$ and respiratory infections. ${ }^{16}$ These volatile oils are widely used in industry due to their broad-spectrum of antimicrobial properties.

*e-mail: 1cab@ufv.br
The Kunzea genus, also from the Myrtaceae family, is endemic to Australia and is recognized mainly for its antimicrobial activity, e.g. Kanuka oil. ${ }^{17}$ Insecticidal activity has also been described for the oils produced by several species, including $K$. ambigua, $K$. baxterii and $K$. ericifolia. The compounds responsible for such an activity have been isolated and characterized. They all contain as a common structural motif the presence of tetramethylcyclohexenedione (or similar) moiety. ${ }^{18}$

The Callistemon genus is closely related to Melaleuca and comprises approximately 30 species endemic in Australia. ${ }^{19}$ Callistemon species are widely used as ornamental and are source of chemical compounds with insecticidal, ${ }^{20}$ antifungal ${ }^{21}$ and antibacterial activities against Escherichia coli, Staphylococcus aureus, Streptococcus pneumoniae e Pseudomonas aeruginosa. ${ }^{22}$ The essential oils of $C$. lanceolatus exhibit activity against Staphylococcus aureus and moderated activity against other Gram-positive and Gram-negative bacteria and fungi Rhizopus oligosporus e Aspergillus niger. ${ }^{23}$

Following our previous investigations on the biological activities and composition of volatile oils from several plant species, ${ }^{24}$ in this work we report the results concerning the chemical composition and antibacterial activities of the volatile oils from seven Myrtaceae species grown in Brazil.

\section{EXPERIMENTAL}

\section{Plant material}

Aerial parts of Melaleuca hypericifolia C. Sm., M. thymifolia Sm., M. linariifolia Sm., Callistemon polandii F. M. Bailey, C. citrinus (Curtis) Skeels, C. viminalis Sol. ex Gartn. and Kunzea ericoides (A. Rich.) J. Thompson were collected in February 2008, from plants grown in the arboretum of the Forest Engineering Department, Dendrology Sector, at the Federal University of Viçosa (UFV), Minas Gerais state, Brazil. Melaleuca samples were obtained from a 10-year old plantation and samples of all the other species came 
from 4-year old plantations. In all cases, the seeds originated from CSIRO - Division of Forestry and Forest Products - Canberra - ACT. The materials were identified, herborized and a voucher specimen of each plant has been deposited in the VIC Herbarium (registration numbers are 31908, 31906, 31905, 30825, 30816, 31116 and 31909) of the Plant Biology Department, Federal University of Viçosa (UFV).

\section{Essential oil extraction}

Leaves were collected separately, in a completely randomized way, from the trees under investigation. Each sample was subdivided into three portions of $100 \mathrm{~g}$ each, chopped and then subjected to a three hours hydrodistillation in a Clevenger-type apparatus. The resulting oils were weighed and the reported yields were calculated with respect to dry matter mass. All distillations were repeated three times and the oils produced in these processes were stored under nitrogen atmosphere, maintained at $-4{ }^{\circ} \mathrm{C}$, until they were analyzed by gas chromatography coupled to a mass spectrometry (GC-MS). Leaf dry matter mass was calculated by drying each sample ( $2 \mathrm{~g}$, held at $103 \pm 2{ }^{\circ} \mathrm{C}$ until constant mass) according to published methods. ${ }^{25}$ Each determination was carried out in triplicate.

\section{Gas chromatography}

GC analyses were carried out with a GC-17A Series instrument (Shimadzu, Japan) equipped with a flame ionization detector (FID). Chromatographic conditions were as follows: fused silica capillary column ( $30 \mathrm{~m} \times 0.22 \mathrm{~mm})$ with a DB-5 bonded phase $(0.25 \mu \mathrm{m}$ film thickness); carrier gas, $\mathrm{N}_{2}$ at a flow rate of $1.8 \mathrm{~mL} \mathrm{~min}^{-1}$; injector temperature $220^{\circ} \mathrm{C}$, detector temperature $240{ }^{\circ} \mathrm{C}$; column temperature was programmed to start at $55^{\circ} \mathrm{C}$ (isothermal for $2 \mathrm{~min}$ ), with an increase of $3{ }^{\circ} \mathrm{C} \mathrm{min}-1$, to $240{ }^{\circ} \mathrm{C}$, isothermal at $240{ }^{\circ} \mathrm{C}$ for $15 \mathrm{~min}$; injection of $1.0 \mu \mathrm{L}\left(1 \% \mathrm{w} / \mathrm{v}\right.$ in $\left.\mathrm{CH}_{2} \mathrm{Cl}_{2}\right)$; split ratio 1:10; column pressure of $115 \mathrm{kPa}$.

The analyses were carried out in triplicate and the amount of each compound was expressed as a relative percentage of the total area of the chromatograms.

\section{Gas chromatography-mass spectrometry (GC-MS)}

The GC-MS unit (model GCMS-QP5050A, from Shimadzu, Japan) was equipped with a DB-5 fused silica column ( $30 \mathrm{~m}$ x $0.22 \mathrm{~mm}$ i.d., film thickness $0.25 \mu \mathrm{m}$ ) and interfaced with an ion trap detector. Oven and injector temperatures were as described above; transfer line temperature, $240{ }^{\circ} \mathrm{C}$; ion trap temperature, $220^{\circ} \mathrm{C}$; carrier gas, He at a flow rate of $1.8 \mathrm{~mL} \mathrm{~min}^{-1}$; injector temperature $220{ }^{\circ} \mathrm{C}$, detector temperature 240 ${ }^{\circ} \mathrm{C}$; column temperature was programmed to start at $55^{\circ} \mathrm{C}$ (isothermal for $2 \mathrm{~min}$ ), with an increase of $3{ }^{\circ} \mathrm{C} \mathrm{min}{ }^{-1}$, to $240{ }^{\circ} \mathrm{C}$, isothermal at 240 ${ }^{\circ} \mathrm{C}$ for $15 \mathrm{~min}$; injection of $1.0 \mu \mathrm{L}\left(1 \% \mathrm{w} / \mathrm{v}\right.$ in $\left.\mathrm{CH}_{2} \mathrm{Cl}_{2}\right)$; split ratio 1:10; column pressure of $100 \mathrm{kPa}$; ionization energy, $70 \mathrm{eV}$; scan range, 29-450 u; scan time, 1s. The identity of each component was assigned by comparison of their retention indexes (RRI), relative to a standard alkane series $\left(\mathrm{C}_{9}-\mathrm{C}_{27}\right)^{26}$ and also by comparison of its mass spectrum with either reference data from the equipment database (Wiley 330,000 ) or from the literature. ${ }^{27}$

\section{Bacterial strains}

Bacterial strains were obtained from the collections of the Department of Microbiology, Federal University of Viçosa, Viçosa, Minas Gerais state Brazil. Microorganisms used were Gram (+) Staphylococcus aureus (ATCC 25923) and Bacillus cereus, Ribotype $1222-173-S 4$ of from equipment surfaces post-pasteurization; ${ }^{28} \mathrm{Gram}$
(-) Escherichia coli (ATCC 11229). Organisms were maintained in nutrient agar (Sigma) at $37^{\circ} \mathrm{C}$. Overnight cultures were prepared in Brain Heart Infusion Broth (Himedia) and adjusted to approximately $10^{8} \mathrm{CFU} \mathrm{mL} \mathrm{m}^{-1}$.

\section{Antibacterial screening}

The agar disc diffusion method was employed to determine the antimicrobial activity of the essential oils, as previously described. ${ }^{29}$ Briefly, a suspension of the tested microorganism $\left(2 \times 10^{8} \mathrm{CFU} \mathrm{mL} \mathrm{mL}^{-1}\right)$ was spread on Petri plates with Mueller Hinton agar. Filter paper discs ( $6 \mathrm{~mm}$ diameter) were individually impregnated with $10 \mu \mathrm{l}$ of the essential oils and placed on the inoculated plates. The plates were incubated for 48 hours at $37^{\circ} \mathrm{C}$ in the cases of $S$. aureus and E. coli and at $32{ }^{\circ} \mathrm{C}$ for $\mathrm{B}$. cereus. The diameters of the inhibition zones were measured using a paquimeter and expressed in millimeters. Positive and negative growth controls were included in each experiment. The antibiotics Vancomycin (30 $\mu \mathrm{g})$, Penicillin G (10 UI), Erythromycin $(15 \mu \mathrm{g})$, Gentamicin $(10 \mu \mathrm{g})$, Streptomycin $(10 \mu \mathrm{g})$, were used as positive controls and sterile water served as negative control. Each test was performed in three triplicates and repeated three times. The results were analyzed by ANOVA and Scott-Knott's multiple-range tests at $\mathrm{P} \leq 0.05$ by using the software GENES (Genetics and Statistical Analysis. Version 2007.0.0 - Federal University of Viçosa, Viçosa - MG, Brazil).

\section{Determinations of minimum inhibitory concentration (MIC) and minimum bactericidal concentration (MBC)}

A broth microdilution method was used to determine the minimum inhibitory concentration (MIC) and the minimum bactericidal concentration (MBC) ${ }^{30} \mathrm{~A}$ serial doubling dilution of each essential oil was prepared in a microtiter tray over the range $0.0156-2 \%$. The broth was supplemented with tween 80 (Merck, Germany) at a concentration of $0.5 \%(\mathrm{v} / \mathrm{v})$ in order to enhance essential oils solubility. Overnight broth cultures of each strain were prepared in Brain Heart Infusion Broth (Himedia) and the final concentration in each well was adjusted to $2 \times 10^{5} \mathrm{CFU} / \mathrm{mL}$ following inoculation. The concentration of each inoculum was confirmed by viable count on Plate Count Agar (Himedia). Positive and negative growth controls were included in every test. The tray was incubated aerobically at $30{ }^{\circ} \mathrm{C}$ (Gramnegative) or $37^{\circ} \mathrm{C}$ (Gram-positive) according to strain and MICs were determined. The MIC is defined as the lowest concentration of the essential oil at which the microorganism tested does not demonstrate visible growth. The bacteria growth was indicated by the turbidity.

To determine MBCs, $100 \mu \mathrm{L}$ broth was taken from each well and inoculated in Mueller-Hinton Agar (Himedia) for $24 \mathrm{~h}$ at 30 or $37^{\circ} \mathrm{C}$. The MBC is defined as the lowest concentration of the essential oil at which $99.99 \%$ or more of the initial inoculum was killed. The number of surviving organism was determined by viable count. All tests were performed in Mueller-Hinton Broth (Himedia) and triplicate.

\section{RESULTS AND DISCUSSION}

Hydrodistillation of fresh leaves of Myrtaceae species gave the followings yields for volatile oils, based on dry weight matter: Melaleuca thymifolia $4.0 \% \pm 0.01 ; M$. hypericifolia $3.8 \% \pm 0.20 ; M$. Linariifolia $1.4 \% \pm 0.02 ;$ Callistemon polandii $0.2 \% \pm 0.00 ;$ C. citrinus $1.1 \% \pm 0.06 ;$ C . viminalis $0.3 \pm 0.00 \%$ and Kunzea ericoides $0.5 \% \pm 0.07$.

The chemical compositions of the volatile oils produced by each one of the seven studied species are presented in Table 1. The essential oils of $K$. ericoides demonstrated a larger predominance of monoterpenes $(66.8 \%)$, being the main component $\alpha$-pinene 
(54.5\%). The oils of Melaleuca and Callistemon are composed in great part by oxygenated monoterpenoids (Table 1). However, the volatile oil of $M$. linariifolia is characterized by a high concentration of methyleugenol ( $86.8 \%)$ and traces of $E$-methylisoeugenol $(0.4 \%)$. Compared with the oils of a M. leucadendra chemotype from Australia (methyleugenol and $E$-methylisoeugenol up to $99 \%$ and $88 \%$ respectively) ${ }^{31}$ and Brazil (96,6\% of methyleugenol), ${ }^{32}$ it seems that the investigated oil has economic potential as a source of methyleugenol, since this compound has an eugenol scent, and could be used in large scale production of perfumes and as food aroma. ${ }^{33}$ The essential oil of $M$. hypericifolia, $C$. viminalis and $C$. citrinus was characterized by a high amount of 1,8-cineole (88.0, 65.0 and $77.0 \%$ respectively). Besides the insecticidal action, this compound also displays anti-inflammatory activity which is associated with its capability to inhibit the cyclooxygenase pathway, preventing prostanoid biosynthesis. ${ }^{34}$ The high content of 1,8-cineole in volatile oils of these species suggests that they can constitute an alternative commercial source of this compound.

Table 1. Chemical constituents of essential oils from Myrtaceae species

\begin{tabular}{|c|c|c|c|c|c|c|c|c|}
\hline CONSTITUENT & RRI & MHS & ML & MT & CVM & CCT & CPL & $\mathrm{KE}$ \\
\hline$\alpha$-thujene & 930 & - & - & $1.4 \pm 0.0$ & - & - & $2.0 \pm 0.2$ & $0.6 \pm 0.0$ \\
\hline$\alpha$-pinene & 935 & $3.0 \pm 0.2$ & - & $1.2 \pm 0.0$ & $12.0 \pm 1.1$ & $3.2 \pm 0.1$ & $1.3 \pm 0.1$ & $54.5 \pm 0.5$ \\
\hline$\beta$-pinene & 979 & $1.2 \pm 0.1$ & - & - & - & $2.2 \pm 0.9$ & - & $1.1 \pm 0.0$ \\
\hline Myrcene & 993 & $0.1 \pm 0.0$ & - & - & - & $3.3 \pm 0.1$ & $0.3 \pm 0.0$ & $0.7 \pm 0.1$ \\
\hline$\alpha$-felandrene & 1004 & - & $0.9 \pm 0.1$ & - & - & - & $6.0 \pm 0.1$ & - \\
\hline$\alpha$-terpinene & 1021 & - & - & - & - & - & $7.5 \pm 0.2$ & $1.0 \pm 0.1$ \\
\hline$\rho$-cymene & 1021 & - & - & $27.7 \pm 0.3$ & $3.6 \pm 0.1$ & - & $7.4 \pm 0.4$ & - \\
\hline o-cymene & 1027 & - & $1.0 \pm 0.3$ & - & - & - & - & - \\
\hline Limonene & 1031 & - & $1.8 \pm 0.3$ & - & - & - & - & - \\
\hline 1,8 -cineole ${ }^{\mathrm{d}}$ & 1041 & $88.0 \pm 0.5$ & - & $7.7 \pm 0.3$ & $65.0 \pm 2.3$ & $77.0 \pm 0.9$ & - & $16.4 \pm 0.5$ \\
\hline$\beta$ - $(E)$-ocinene & 1053 & - & - & - & - & $0.7 \pm 0.0$ & - & $0.7 \pm 0.2$ \\
\hline$\gamma$-terpinene ${ }^{\mathrm{d}}$ & 1065 & - & - & - & - & $0.7 \pm 0.0$ & $16.8 \pm 1.6$ & $4.1 \pm 0.0$ \\
\hline$\alpha$-terpinolene & 1089 & - & - & - & - & - & - & $0.9 \pm 0.1$ \\
\hline Linalool & 1103 & - & $0.6 \pm 0.0$ & - & $1.1 \pm 0.1$ & - & - & $1.5 \pm 0.0$ \\
\hline$E$-pinocarveol & 1133 & - & - & - & $2.3 \pm 0.4$ & - & - & - \\
\hline$Z$-pinene hydrate & 1123 & - & - & - & - & - & $0.3 \pm 0.1$ & - \\
\hline Terpinen-4-ol $^{\mathrm{d}}$ & 1181 & $3.3 \pm 0.2$ & $0.3 \pm 0.0$ & $47.0 \pm 0.2$ & $1.4 \pm 0.2$ & $0.4 \pm 0.0$ & $49.8 \pm 1.1$ & - \\
\hline p-cimen-8-ol & 1187 & - & - & - & - & - & $2.3 \pm 0.1$ & - \\
\hline$\alpha$-terpineol ${ }^{\mathrm{d}}$ & 1195 & $0.2 \pm 0.1$ & $0.8 \pm 0.0$ & $3.2 \pm 0.1$ & $13.0 \pm 1.6$ & $8.9 \pm 0.4$ & $0.3 \pm 0.1$ & $5.7 \pm 0.1$ \\
\hline Not identified & 1261 & - & - & $4.2 \pm 0.2$ & - & - & - & - \\
\hline Methyl eugenol $^{\mathrm{d}}$ & 1415 & - & $86.8 \pm 0.3$ & - & - & - & - & - \\
\hline$E$-cariophyllene & 1424 & - & - & - & - & $0.4 \pm 0.1$ & - & - \\
\hline Aromadendrene & 1443 & $0.1 \pm 0.3$ & - & - & - & - & - & - \\
\hline$\alpha$-humulene & 1450 & - & $0.5 \pm 0.2$ & - & - & - & - & - \\
\hline Germancrene D & 1477 & - & $1.4 \pm 0.6$ & - & - & - & - & - \\
\hline Bicyclogermacrene & 1494 & - & $0.9 \pm 0.2$ & - & - & - & - & $3.2 \pm 0.3$ \\
\hline$E$-methylisoeugenol & 1506 & - & $0.4 \pm 0.1$ & - & - & - & - & - \\
\hline Ledol & 1566 & - & - & - & $1.5 \pm 0.7$ & - & - & $0.4 \pm 0.0$ \\
\hline Spathulenol & 1585 & $0.1 \pm 0.1$ & $0.3 \pm 0.1$ & - & - & $0.5 \pm 0.1$ & - & $1.0 \pm 0.0$ \\
\hline Globulol & 1591 & $0.1 \pm 0.0$ & - & - & - & $0.4 \pm 0.1$ & - & - \\
\hline Viridiflorol & 1585 & - & - & - & - & - & - & $3.3 \pm 0.0$ \\
\hline Yield (\%) & & 96.1 & 95.7 & 92.4 & 99.9 & 97.7 & 94.0 & 95.1 \\
\hline $\begin{array}{l}\text { Monoterpene Hydro- } \\
\text { carbons/ Oxygenated }\end{array}$ & & $4.4 / 91.7$ & $6.5 / 2.0$ & $30.3 / 57.9$ & $15.6 / 84.3$ & $10.5 / 87.2$ & $41.6 / 52.4$ & $66.8 / 28.3$ \\
\hline Others & & - & 87.2 & 4.2 & - & - & - & - \\
\hline
\end{tabular}

RRI: relative retention indices relative to $\mathrm{C}_{9}-\mathrm{C}_{27} n$-alkanes on a DB5 column. $\mathrm{MHS}=$ Melaleuca hypericifolia, $\mathrm{ML}=$ M. linariifolia; $\mathrm{MT}=$ M. thymifolia; $\mathrm{CVM}=$ Callistemon viminalis $; \mathrm{CCT}=C$. citrinus $; \mathrm{CPL}=C$. polandii $; \mathrm{KE}=$ Kunzea ericoides 
The essential oil of $M$. thymifolia and $C$. polandii presented terpinen-4-ol as the major component (47.0 and $49.8 \%$ respectively). Terpinen-4-ol is one of the major and active components of Tea Tree Oil (TTO), the volatile oil steam distilled from M. alternifolia, and of great commercial value. ${ }^{35}$ The main component of the essential oil of Kunzea ericoides is $\alpha$-pinene (54.5\%). This substance is used as a precursor for the preparation of synthetic mosquito repellents ${ }^{36}$ with low toxicity to humans.

The evaluation of antimicrobial activity by the Agar disc diffusion method showed that the volatile oils isolated from the seven studied species showed different levels of antibacterial activity (Table 2). In general these oils were less active than most of the antibiotics evaluated. With exception of $M$. thymifolia, the volatile oils from all other species exhibited low activity. The essential oil of M. thymifolia was the most active against all bacteria. It was more active against $S$. $a u$ reus than Gentamicin and Streptomycin. The antimicrobial activity of the oil of M. thymifolia was evaluated by determining of the minimal inhibitory concentration (MIC) and minimum bactericidal concentration (MBC). The results are presented in Table 3 and indicated that the oil exhibited strong activity against all microorganisms tested.

Table 2. Antibacterial activity of essential oils from Myrtaceae species Inhibition zone diameter ( $\mathrm{mm})$

\begin{tabular}{cccc}
\hline Microorganisms & $G(-)$ & \multicolumn{2}{c}{$G(+)$} \\
& E. coli & S. aureus & B. cereus
\end{tabular}

Essential Oil

\begin{tabular}{lccl} 
M. linariifolia & $08.0 \mathrm{Af}$ & $09.0 \mathrm{Ai}$ & $09.0 \mathrm{Af}$ \\
M. hypericifolia & $10.0 \mathrm{Af}$ & $08.0 \mathrm{Ai}$ & $10.6 \mathrm{Ae}$ \\
M. thymifolia & $22.8 \mathrm{Ac}$ & $19.9 \mathrm{Bg}$ & $23.6 \mathrm{Ab}$ \\
C. viminalis & $13.0 \mathrm{Ae}$ & $08.6 \mathrm{Bi}$ & $13.6 \mathrm{Ad}$ \\
C. polandii & $08.8 \mathrm{Af}$ & $08.7 \mathrm{Ai}$ & $10.3 \mathrm{Ae}$ \\
C. citrinus & $07.5 \mathrm{Af}$ & $09.2 \mathrm{Ai}$ & $08.6 \mathrm{Af}$ \\
K. ericoides & $06.0 \mathrm{Bg}$ & $09.7 \mathrm{Ai}$ & $10.3 \mathrm{Ae}$ \\
Standards & & & \\
Vancomycin $30 \mu \mathrm{g}$ & $12.7 \mathrm{Be}$ & $24.3 \mathrm{Af}$ & $13.0 \mathrm{Bd}$ \\
Penicillin G $10 \mathrm{UI}$ & $07.7 \mathrm{Bf} *$ & $51.3 \mathrm{Aa}$ & $08.3 \mathrm{Bf}$ \\
Erythromycin $15 \mu \mathrm{g}$ & $06.0 \mathrm{Cg} *$ & $31.3 \mathrm{Ae}$ & $18.0 \mathrm{Bc}$ \\
Gentamicin $10 \mu \mathrm{g}$ & $16.0 \mathrm{Bd}$ & $17.7 \mathrm{Bg}$ & $19.7 \mathrm{Ac}$ \\
Streptomycin $10 \mu \mathrm{g}$ & $16.0 \mathrm{Bd}$ & $15.0 \mathrm{Bh}$ & $24.0 \mathrm{Ab}$ \\
Control & $06.0 \mathrm{Ag}$ & $06.0 \mathrm{Aj}$ & $06.0 \mathrm{Ag}$ \\
\hline
\end{tabular}

Means followed by same capital letter in the lines and small letter in the columns are not different for the Scott-Knott's test at $\mathrm{P} \leq 0.05$. * resistant strain.

Table 3. Minimum inhibitory concentration and minimum bactericidal concentration data (\% v/v) obtained by microdilution method of $M$. thymifolia essential oil

\begin{tabular}{lccc}
\hline \multicolumn{3}{c}{ Bacteria } \\
\hline & E. coli & S. aureus & B. cereus \\
MIC & 0.0625 & 0.0625 & 0.0625 \\
MBC & 0.125 & 0.0310 & 0.125 \\
\hline
\end{tabular}

Although the volatile oils obtained from M. hypericifolia, Callistemon viminalis and $C$. citrinus have high content of 1,8-cineole (88.0, 65.0 and $77.0 \%$ respectively), a well known compound with pronounced antimicrobial potentials, the essential oil from this species showed low activity. Likewise, the essential oils of $K$. ericoides, mainly composed of monoterpene hydrocarbons especially to its majority component, $\alpha$-pinene $(54.5 \%)$ presented a very weak antibacterial activity. $\alpha$-Pinene seem to be able to disintegrate the cellular integrity, and causes inhibition of respiration and ion transportation process. ${ }^{37}$ Cerqueira et al. ${ }^{38}$ studied the essential oil of Myrcia myrtifolia (Myrtaceae) that presents $87.3 \%$ of $\alpha$-pinene and showed strong activity against $S$. aureus, methicilin resistant $S$. aureus and $C$. albicans. Some studies have concluded that whole essential oils have a greater antibacterial activity than the major components mixed, ${ }^{39}$ which suggests that the minor components are critical to the activity and may have a synergistic effect or potentiating influence. Besides, the mode of action of the essential oil seems depending on the bacterial strain. Furthermore, it is also noteworthy that synergistic and/or antagonistic effects might be taken intoaccount for the activity observed in complex mixtures, such as essential oils. ${ }^{40}$

The essential oils from $M$. thymifolia and C. polandii presented terpinen-4-ol as the major component (47.0 and $49.8 \%$ for respectively), but $M$. thymifolia showed the best activity. The essential oil produced by $M$. thymifolia contained just one compounds that were not observed in the oils of $C$. polandii $(1,8$-cineol $7.7 \%)$, and contained $p$-cymene in higher concentration $(27.7 \%)$ (Table 1). $p$ Cymene is a biological precursor of carvacrol and is hydrophobic. This compound causes swelling of the cytoplasmic membrane to a greater extent than does carvacrol. ${ }^{41}$ But $p$-Cymene is not an effective antibacterial when used alone. ${ }^{42}$ When combined with carvacrol, synergism has been observed..$^{43}$ The best antimicrobial activity of the essential oils from $M$. thymifolia might be attributed to a synergistic action of other compounds present in the oil.

In conclusion, the results described demonstrate the promising possibility of using of the essential oils from M. thymifolia as an alternative to some antibiotics against Gram (+) and Gram (-) bacteria.

\section{REFERENCES}

1. Essawi, T.; Srour, M.; J. Ethnopharmacol. 2000, 70, 343.

2. Kaferstein, F. K.; Mortarjemi, Y.; Bettcher, D. W.; Emerg. Infect. Dis. 1997, 3, 503.

3. Nychas, G. J. E. In New methods of food preservation; Gould, G. W., ed.; Blackie Academic Professional: London, 1995, p. 58.

4. Craven, L. A.; Lepschi, B. J.; Aust. Syst. Bot. 1999, 12, 819.

5. Caldefie-Chezet, F.; Fusillier, C.; Jarde, T.; Laroye, H.; Damez, M.; Vasson, M. P.; Guillot, J.; Phytother. Res. 2006, 20, 364.

6. Bagg, A. J.; Jackson, M. S.; Sweeney, M. P.; Ramage, G.; Davies, A. N.; Oral Oncol. 2006, 42, 487.

7. Iori, A.; Grazioli, D.; Gentile, E.; Marano, G.; Salvatore, G.; Vet. Parasitol. 2005, 129, 173.

8. Minami, M.; Kita, M.; Nakaya, T.; Yamamoto, T.; Kuriyama, H.; Imanishi, J.; Microbiol. Immunol. 2003, 47, 681.

9. Hussein, S. A. M.; Hashim, A. N. M.; El-Sharawy, R. T.; Seliem, M. A.; Linscheid, M.; Lindequist, U.; Nawwar, M. A. M.; Phytochemistry 2007, $68,1464$.

10. Carson, C. F.; Riley, T. V.; Cookson, B. D.; J. Hosp. Infect. 1998, 40, 175.

11. Giordani, C.; Molinari, A.; Toccacieli, L.; Calcabrini, A.; Stringaro, A.; Chistolini, P.; Arancia, G.; Diociaiuti, M.; J. Med. Chem. 2006, 49, 4581 .

12. Budhiraja, S. S.; Cullum, M. E.; Sioutis, S. S.; Evangelista, L.; Habanova, S. T.; J. Manipul. Physiol. Therap. 1999, 22, 447.

13. Wendy, W. J. S.; Ahmed, H. F.; Thomas, V. R.; Verbrugh, H.; Belkum, A.; J. Antimicrob. Chemother. 2007, 59, 553.

14. Mondello, F.; De-Bernardis, F.; Girolamo, A.; Salvatore, G.; Cassone, A.; J. Antimicrob. Chemother. 2003, 51, 1223. 
15. Caelli, M.; Porteous, J.; Carson, C. F.; Heller, R.; Riley, T. V.; J. Hosp. Infectol. 2000, 46, 236.

16. Juergens, U. R.; Dethlefsen, U.; Steinkamp, G.; Gillissen, A.; Repges, R.; Vetter, H.; Respir. Med. 2003, 97, 250.

17. Porter, N. G.; Wilkins, A. L.; Phytochemistry 1998, 50, 407.

18. Khambay, B. P. S.; Beddie, D. G.; Simmonds, M. S. J.; Phytochemistry 2002, 59, 5969.

19. Mabberley, D. J.; The Plant-Book. A portable dictionary of the higher plants, $4^{\text {th }}$ ed., Cambridge University Press: New York, 1993; Craven, L. A. In Tea Tree: The Genus Melaleuca; Southwell, I. A.; Lowe, R., eds.; Harwood Academic Publ.: Australia, 1999, p. 11.

20. Khambay, B. P. S.; Beddie, D. G.; Hooper, A. M.; Simmonds, M. S. J.; Green, P. W. C.; J. Nat. Prod. 1999, 62, 1666.

21. Last, D. I.; Llewellyn, D. J.; New Zealand J. Bot. 1997, 35, 385.

22. Chohan, Z. H.; Pervez, H.; J. Nat. Sci. Math. 1999, 39, 157.

23. Sudhakar, M.; Raju, D. B.; Int. J. Chem. Sci. 2005, 3, 513.

24. Martins, E. R.; Casali, V. W. D.; Barbosa, L. C. A.; Carazza, F.; J. Braz. Chem. Soc. 1997, 8, 29 ; Barbosa F. D. F.; Barbosa, L. C. A.; Melo, E. C.; Botelho, F. M.; Quim. Nova 2006, 29, 122; Martins, F. T.; Santos, M. H.; Pólo, M.; Barbosa, L. C. A.; Quim. Nova 2006, 29, 1203; Castro, H. G.; Oliveira, L. O.; Barbosa, L. C. A.; Ferreira, F. A.; Silva, D. J. L.; Mosquim, P. R.; Nascimento, E. A.; Quim. Nova 2004, 27, 55; Barbosa, L. C. A.; Demuner, A. J.; Teixeira, R. R.; Madruga, M. S.; Fitoterapia 1999, 70, 152; Barbosa, L. C. A.; Paula, V. F.; Azevedo, A. S.; Silva, E. M. M.; Nascimento, E. A.; Flavour Frag. J. 2005, 20, 39; Silva, A. F.; Barbosa, L. C. A.; Nascimento, E.; Casali, V. W. D.; J. Essent. Oil Res. 2000, 12, 725; Fonsceca, M. C. M.; Barbosa, L. C. A.; Nascimento, E. A.; Casali, V. W. D.; J. Essent. Oil Res. 2006, 18, 345.

25. American Society of Agricultural Engineers; Standards Engineering Practices Data, Moisture Measurement ASAE S358.2 DEC99, Forages, 2000 .

26. van den Dool, H., Kratz, P. D. J.; J. Chromatogr. 1963, 11, 463.

27. Adams R. P.; Identification of essential oil components by gas chromatography/mass spectroscopy, Allured Publishing Corporation: Illinois, 1995.
28. Salustiano, V. C.; Andrade, N. J.; Soares, N. F. F.; Lima, J. C.; Bernardes, P. C.; Luiz, L. M. P.; Fernandes, P. E.; Food Control 2009, $20,439$.

29. National Committee for Clinical Laboratory Standards; Performance standards for antimicrobial susceptibility test. Ninth International Supplement, M100-S9, NCCLS: Wayne, 1997.

30. National Committee for Clinical Laboratory Standards; Performance standards for antimicrobial susceptibility test. Ninth International Supplement. M100-S9, Wayne, PA. 1999; Carson, C. F.; Hammer, K. A.; Riley, T.V.; Microbios 1995, 82, 181.

31. Brophy, J. J.; Lassak, E. V.; Flav. Frag. J. 1988, 3, 43.

32. Silva, C. J.; Barbosa, L. C. A. B.; Maltha, C. R. A.; Pinheiro, A. L.; Ismail, F. M. D.; Flav. Frag. J. 2007, 22, 474.

33. Halcon, L; Milkus, K.; Am. J. Infect. Control. 2004, 32, 402.

34. Dewhirst, F. E.; Prostaglandins 1980, 20, 209.

35. Altman, P. M.; Aust. J. Pharm. 1988, 69, 276.

36. Wang, Z.; Song. J.; Chen, J.; Song, Z.; Shang, S.; Jiangd, Z.; Han, Z.; Bioorg. Medic. Chem. Lett. 2008, 18, 2854.

37. Sikkema, J.; de Bont, J. A. M.; Poolman, B.; J. Biol. Chem. 1994, 269 , 8022; Cox, S. D.; Mann, C. M.; Karkham, J. L.; Bell, H. C.; Gustafson, J. E.; Warmington, J. R.; Wyllie, S. G.; J. Appl. Microbiol. 2000, 88, 170.

38. Cerqueira, M. D.; Souza-Neta, L. C.; Passos, M. G. V. M.; Lima, E. O.; Roque, N. F.; Martins, D.; Guedes, M. L. S.; Cruz, F. G.; J. Braz. Chem. Soc. 2007, 18, 998.

39. Gill, A. O.; Delaquis, P.; Russo, P.; Holley, R. A.; Int. J. Food Microbiol. 2002, 73, 83; Mourey, A.; Canillac, N.; Food Control 2002, 13, 289.

40. Kelen, M.; Tepe, B.; Bioresour. Technol. 2008, 99, 4096.

41. Ultee, A.; Bennink, M. H. J.; Moezelaar, R.; Appl. Environ. Microbiol. 2002, 68, 1561.

42. Juven, B. J.; Kanner, J.; Schved, F.; Weisslowicz, H.; J. Appl. Bacteriol. 1994, 76, 626; Dorman, H. J. D.; Deans, S. G.; J. Appl. Bacteriol. 2000, 88, 308; Juliano, C.; Mattana, A.; Usai, M.; J. Essential Oil Res. 2000, $12,516$.

43. Ultee, A.; Kets, E. P. W.; Alberda, M.; Hoekstra, F. A.; Smid, E. J.; Arch. Microbiol. 2000, 174, 233. 